\title{
RECENZJE
}

\author{
KRYSTYNA HELAND-KURZAK* \\ Warszawa, Polska \\ ORCID ID: https://www.orcid.org/oooo-0oo2-6130-4644
}

Forum Pedagogiczne 10 (2020) 1

Wpłynęło: 10.01.2020 Zatwierdzono do druku: 18.03.2020 DOI: $10.21697 / \mathrm{fp} .2020 .1 .23$

\section{Społeczne formy uczestnictwa i problem wiedzy milczącej}

[Harry Collins (2010). Tacit and Explicit Knowledge. Chicago-London: The University od Chicago Press, 202 s.]

Pojęcia wiedzy jawnej i niejawnej nie są silne eksponowane w literaturze pedagogicznej. Najczęściej pojawiają się one w aspekcie ukrytego programu szkoły, co stanowi tylko część omawianej problematyki, i to bardzo wąską. Pojęciowe rozróżnienie wiedzy jawnej (explicit knowledge) i wiedzy niejawnej (tacit knowledge) pojawiło się po raz pierwszy w pracach Michaela Polanyiego w 1958 roku. Od tego czasu powstało bardzo dużo prac bazujących na jego odkryciach dotyczących instytucjonalnych form organizacji nauki. Tak więc najczęściej, i to w literaturze zagranicznej, powstają prace z zakresu zarządzania. W literaturze polskiej, na gruncie filozofii, rozpoczęto rzetelne badania dotyczące tej problematyki (głównie robi to Iwo Zmyślony, a najważniejszą jego pracą jest praca doktorska dotycząca analizy poglądów metodologicznych i epistemologicznych Polanyiego). W pracach pedagogicznych ten problem właściwie nie istnieje samodzielnie.

Recenzowana książka jest usystematyzowaniem wcześniejszych prac Collinsa. Dla czytelnika rok publikacji 2010 może wydawać się „stary”, jednak wziąwszy pod uwagę to, że po tylu latach Collins nie doczekał się tłumaczenia w języku polskim ani rzetelnych opracowań, ani zastosowań na szerszą skalę, staje się to zasadne i słuszne.

Struktura książki została podzielona na trzy główne części. Pierwsza część porusza kwestie wiedzy jawnej. Trzeba przyznać, że nie można zrozumieć z filozoficznego punktu widzenia, czym jest wiedza ukryta, jeśli nie zrozumie się tego, czym jest wiedza jawna. Autor eksploruje wiedzę jawną, poświęcając jej 70 stron (z 202 łącznie). Druga część dotyczy wiedzy niejawnej. Autor prezentuje w niej napięcie istniejące w wiedzy ukrytej, owo napięcie między „nie ma” a „nie może” przenika całą dyskusję. Wydawałoby się, że ta część jest najistotniejsza dla rozważań Collinsa, ale jak sam autor zauważa w kilku miejscach swojej monografii,

* Dr Krystyna Heland-Kurzak, Akademia Pedagogiki Specjalnej im. M. Grzegorzewskiej w Warszawie, Wydział Nauk Pedagogicznych; e-mail: kheland@aps.edu.pl. 
to tylko pojęciowe wprowadzenie do najważniejszej, trzeciej części. W niej, obok narysowania całej mapy wiedzy ukrytej, próbuje m.in. odpowiedzieć na nurtujące go pytania, czy wiedzę niejawną można wyrazić w zupełności (całościowo), czy też tylko pewne jej aspekty lub przejawy. Pokazuje również, że w zasadzie różnych rodzajów wiedzy ukrytej człowiek uczy się lub może się uczyć poprzez sam fakt uczestnictwa w różnych formach życia społecznego.

Collins rozpoczyna omówienie wiedzy jawnej i niejawnej (milczącej) od przedstawienia najważniejszego pojęcia - string. String („struna”, „łańcuch”, „jakiś ciąg”) zawiera pewną informację $\mathrm{w}$ sensie związanym $\mathrm{z}$ teorią informacji. Można powiedzieć, że jest to fizyczna/materialna rzecz, niosąca w sobie pewien ładunek informacyjny. Sama w sobie nie ma on wartości, nabiera jej dopiero w zetknięciu z działaniem człowieka. Na dalszym etapie autor przedstawia trzy rodzaje wiedzy niejawnej (milczącej), a są nimi: (1) Relacyjna Wiedza Niejawna (RTK); (2) Somatyczna Wiedza Niejawna (STK); (3) Zbiorowa Wiedza Milcząca (CTK). Najtrudniej jest penetrować najbardziej wewnętrzny region wiedzy ukrytej/niejawnej, gdyż „idea wiedzy ukrytej/niejawnej powstaje z jej napięcia z ideą jawności” (s. 158).

Relacyjna wiedza ukryta/niejawna (kategoria wprowadzona przez Collinsa, nikt wcześniej jej nie konceptualizował) - polega na tym, że uczestnicy określonych interakcji mogą kierować się utajonymi racjami, które uwidaczniają się dopiero w bezpośrednich (osobistych) formach kontaktu. Collins dodatkowo wyróżnia pięć kategorii wiedzy ukrytej/niejawnej (pierwsze cztery dotyczą relacyjnej wiedzy) (s. 110): (1) concealed knowledge - wiedza maskowana lub wiedza pozorowana; (2) mismatched saliences - niedopasowany związek; niedopasowana istotność (inaczej: być nie w temacie); (3) ostensive knowledge - wiedza ostensywna, a zatem wiedza, której nie da się wyrazić słowami i trzeba ją jakoś pokazać/wyrazić, np. gestem; (4) unrecognized knowledge - wiedza nierozpoznana; (5) uncognized/ uncognizable knowledge - wiedza poznana/niepoznana.

Generalnie: relacyjna wiedza ukryta/niejawna pokazuje, że aby uczyć się od innych, nie wystarczy tylko styczność z wytworami ich działań, np. z tym, co napisali lub wytworzyli. Potrzebne są również osobiste, niezapośredniczone formy interpersonalnych interakcji. Normalny przebieg socjalizacji obejmuje bowiem zdobycie zbiorowej wiedzy milczącej. A zatem, z im większą ilością bezpośrednich kontaktów międzyludzkich mamy do czynienia, tym bardziej czytelne stają się dla nas różne formy komunikacji, jakie kontaktom tym towarzyszą. Co więcej, można powiedzieć, że są takie obszary doświadczenia i wiedzy, których nie można zrozumieć bez uwzględniania określonych kontekstów związanych z bezpośrednimi interakcjami międzyludzkimi.

Wszystkich rodzajów wiedzy milczącej (RTK, STK, CTK) uczymy się zatem, partycypując $\mathrm{w}$ różnych formach życia społecznego. W ten sposób wchodzimy w relacje społeczne, które skutkują wyjaśnieniem różnych aspektów lub przejawów ukrytej/niejawnej wiedzy relacyjnej. Błędem byłoby jednak sądzić - jak przekonuje 
nas Collins - że całą wiedzę ukrytą moglibyśmy uczynić jawną, nawet przy największych staraniach wszystkich ekspertów. Czym więc jest ta wiedza ukryta, która pozostała i pozostanie w całości właśnie taką, a my możemy poznać jedynie określone jej aspekty lub przejawy? To bardzo znacząca część naszego świata, jego społecznych i kulturowych reprezentacji. To ona określa nasz język, naukę, edukację, zarządzanie, sport, czy też - jak stwierdza Collins - jazdę na rowerze, sztukę i nasze posługiwanie się różnymi technologiami i urządzeniami. W milczącej wiedzy jest coś, co podlega zatajeniu, a co staje się zarówno naszym udziałem, jak i przedmiotem rozpoznania $\mathrm{w}$ ramach różnych form społecznego uczestnictwa i uczenia się. Collins twierdzi, że wiedza ukryta sprawia np., że ludzie zamieniają komputery ze zwykłych, bezrozumnie pobrzmiewających/działających urządzeń „w przydatnych asystentów” (s. 17). Kiedy więc twierdzimy, że „nie można” przewidzieć, w jaki sposób tego rodzaju milcząca wiedza mogłaby stać się jawna”, to zakładamy, że jak na razie nie da się tego jednoznacznie rozstrzygnąć, odwołując do się naukowych ustaleń.

Aby lepiej zobrazować ideę wiedzy ukrytej swoim czytelnikom, Collins posługuje się innymi jej nazwami. Wiedza ukryta zbiorowa jest to więc silna wiedza, która jest domeną wiedzy zlokalizowanej w społeczeństwie. Co ważne, nie umiemy tego wyrazić, czy też nie umiemy w sposób prosty i nieproblematyczny uczynić z niej wiedzy jawnej.

Według Collinsa istoty wiedzy powinniśmy szukać w zbiorowej wiedzy niejawnej. W wiedzy zbiorowej możemy zaś rozróżnić działania monomorficzne i polimorficzne. Te pierwsze oznaczają to, co chcemy robić za każdym razem w ten sam sposób, prawie tak, jakbyśmy byli maszynami. Klasycznym przykładem takiego ludzkiego działania może być wypełnianie formularzy urzędowych. Działania polimorficzne są naturalnie i odpowiednio zmienne oraz zakorzenione w interakcjach oraz celach społecznych i ludzkich. Rozmowa jest kanonicznym przykładem działania polimorficznego. Według Collinsa nadal celowo lub nieumyślnie zwraca się uwagę na powierzchowne sztuczki, odległe od głębokich ujęć rzeczywistych problemów. W społeczeństwie dwa mechanizmy wspierają ten proces „ogłupiania”. Po pierwsze, zmiana sposobu, w jaki żyjemy, inaczej mówiąc, zmechanizowanie działań ludzkich, czyniące z działań polimorficznych czynności monomorficzne. Po drugie, reprodukowanie zbiorowej wiedzy niejawnej, z czym mamy dzisiaj do czynienia. Aby zrozumieć, w jaki sposób milczenie zamienia się w jawność, trzeba zacząć od idei, że „ludzie są wyjątkowi, ponieważ posiadają zbiorową wiedzę milczącą, której nie podzielą ze zwierzętami i rzeczami; daje im to asymetryczną moc do organizowania wszystkich rzeczy" (s. 164), które sprowadzone zostają do tego, co postrzegane jest jako własne „ja” lub wyraża nasze wspólne formy życia społecznego (s. 166).

Przedstawiona monografia pozwala lepiej zrozumieć rolę i znaczenie wiedzy niejawnej (ukrytej, milczącej). Wydaje się też, że pojęcie zbiorowej/kolektywnej wiedzy milczącej, wyrażające różne skrypty form życia społecznego, ważne jest nie 
tylko dla socjologów, lecz także potencjalnie stanowi istotny obszar problemowy dla teorii i praktyki pedagogicznej. Trudno bowiem nie zgodzić się ze stwierdzeniem, że dzieci w swych społecznych formach przystosowania w dużej mierze uczą się określonych umiejętności oraz przyswajają sobie określone sposoby rozumowania i działania poprzez bezpośrednie interakcje zarówno z osobami socjalizująco znaczącymi, jak i samym środowiskiem społecznym, częścią którego są określone zasoby wiedzy milczącej. 